doi:10.7592/EP.2.sarv

\title{
Traditional Estonian lullabies. A tentative overview
}

\author{
Mari Sarv
}

\begin{abstract}
Estonian folk lullabies belong to the common heritage of Baltic-Finnic runosong tradition. The article surveys the older layer of lullaby recordings that are kept in the Estonian Folk Archive, in order to throw light on the essence of Estonian lullabies. The history of collecting lullabies, their content, form, performance and use will be discussed. The author concludes that performed lullabies were created by combining the traditional elements on the one hand, and improvised, situation-based elements on the other. Archived recordings represent mostly the more stable, traditional parts of lullabies. Nevertheless, several features of the corpus indicate the importance of improvisation in the performance of traditional lullabies.
\end{abstract}

Keywords: Estonian folklore, regilaul, runosong, lullabies, versification, Kalevala-metric poetry, oral tradition

Putting babies to sleep by singing to them is a practice known across very different cultures. These songs have something in common, but they also bear marks of uniqueness, features specific to a particular language and culture. Estonian traditional lullabies belong largely to the archaic layer of Estonian folk songs - among the runosongs (in Estonian regilaul). The Estonian runosong forms a part of a wider communal Baltic-Finnic indigenous tradition, the typical features of which are present in other forms of Estonian folklore as well, as seen in different genres from songs to proverbs. Its formulaic structure is mainly based on the semantically integrated use of alliteration and parallelism, well visible in its usually eight-syllable non-rhyming verses. The poetic form of runosongs is so peculiar and tied to the essence of the language that it leads to thinking that no other culture or language could have something even remotely similar. At the same time, the lullabies of neighbouring nations are quite similar to Estonian ones, even if only content-wise. This raises a justified question: what is the essence of truly Estonian lullabies. 


\section{On the history of collecting runosongs and folk poetry in Estonia}

In the course of an active modernisation of the society, the tradition of archaic runosongs almost disappeared across the whole country during the $19^{\text {th }}$ and $20^{\text {th }}$ centuries. Nations - defined by their language and culture - gained major political importance in Europe (see e.g. Anderson 1983). Estonians, by that time freed from serfdom, attempted to establish themselves as a cultured nation, with the Baltic Germans setting the closest example for them. The Baltic Germans had been settled in Estonia already since the crusades (in the $13^{\text {th }}$ century) and had imposed their superiority on the locals, who were considered the subjugated class. During the period of modernisation, more and more Estonian-language literature (fiction as well as non-fiction) was published, whereas people initially tried to imitate the German culture as closely as possible (see also Kalmre 2013: 27 , this volume). This brought along a stigmatisation of old traditions, beliefs, and also of the runosongs, which were linked to the older layer of culture. The nation adopted a German style of singing; in the vein of German music tradition, brass bands and singing choirs were established in Estonia (see e.g. ERTA I: 172). This was a part of a cultural change, also known in academic literature as "self-colonisation", a term which designates the process whereby a foreign cultural model is voluntarily adopted through imitating the higher classes (Hennoste 2007).

Nevertheless, there was an increasing need to prove the Estonian own cultural capability during the period of national awakening. The Estonians had remained in the position of a lower social class with limited options for education after the land was conquered by foreign powers. One of the first consequences of the need to prove Estonian cultural worth was conceived by a doctor of Estonian descent, Friedrich Reinhold Kreutzwald, who wrote the epic "Kalevipoeg" (1853), which was based on the content of Estonian runosongs and tried to follow also the verse structure of the old tradition. The epic, archaic in form but modernist in thought, has remained one of the leading works of Estonian national literature (Talvet 2011). Another similar benchmark was set by collections of national folklore, initiated by Jakob Hurt in 1888. He called for the whole nation to collect all traditional wisdom from among the people, planning to publish the material in edited folk collections. Calls for this action, emphasising the national spirit of the enterprise, were published in newspapers, and as a result, the more mentally agile and literate citizens sent hundreds and hundreds of pages of folklore, collected from among the people, to Jakob Hurt and Matthias Johann Eisen. The Estonian Student's Society (Eesti Üliõpilaste Selts) continued this endeavour in the beginning of the $20^{\text {th }}$ century, collecting 
folk melodies. From then on, collecting folklore became less intense, but was nevertheless constantly carried on. In 1927, the Estonian Folk Archive was established, which took the responsibility of storing all the bigger folk collections. The collections that were until then in private hands were made available to the public, the registry books and cardfile systems to access the materials were established (see e.g. Järv \& Sarv 2013). The archive also began to coordinate folklore collecting campaigns and is doing it up to this day.

The earliest records of lullabies can be found in the writings of a few educated intellectuals who were interested in the Estonian culture. For example, an Estophile of Baltic German descent, Alexander Heinrich Neus, published four lullabies with (partly erroneous) German translations in his bulky volume of folk songs (1850-1852: 411-412). From his correspondence with Kreutzwald (Kreutzwald 1956: 11-225) we can read that he asked the latter for songs sung by children and nannies as well as for lullabies, writing that "these are not present in our collections, though I have been told that they exist" (ibid.: 17). Kreutzwald then sent to Neus three lullabies that he had collected, commenting on these in one of his following letters: "The lullabies I sent you earlier were completely worthless; I sent these as mere examples because you told me you have nothing from that genre. They almost seem to me as imitations of German lullabies, especially as I heard these from a nanny who was employed in a manor house" (ibid.: 39). The first one of the four texts in Neus's publication is recognisably a runosong from southern Estonia (see Figure 1), but the following three (those sent by Kreutzwald) are similar to runosongs in their use of lulling words but lack the alliterative-parallelistic elements in the rest of the verses. In comparison with lullabies that were written down later, the three songs indeed come across as rather sketchy or fleeting, and their contents are based on motives that are not present in other lullabies.

In his call for collecting folklore, Jakob Hurt advises to seek for songs during communal festivities, ask women singing in the fields, or to find an old woman who knows many songs (e.g. Hurt 1989: 33). He does not mention lullabies in his calls, and there are only a few of these in his material, especially if compared to the collections from later periods - only 128 texts, which is less than 0,27 per cent of all runosong texts in Hurt's collections.

It is not possible to give exact statistical overview of later folk collections, but a definite increase of lullabies can be witnessed there. Walter Anderson's collection (1920-1939) displays a fair proportion of lullabies, as it consists of folklore collected by school children from among themselves and their families. The share of runosongs in the material is not big; yet, children have been encouraged to report the lullabies they were familiar with. The proportion of lullabies in the database of runosong melodies (mostly collected during the $20^{\text {th }}$ century) is 4,6 per cent. 


\section{Mari Sarv}

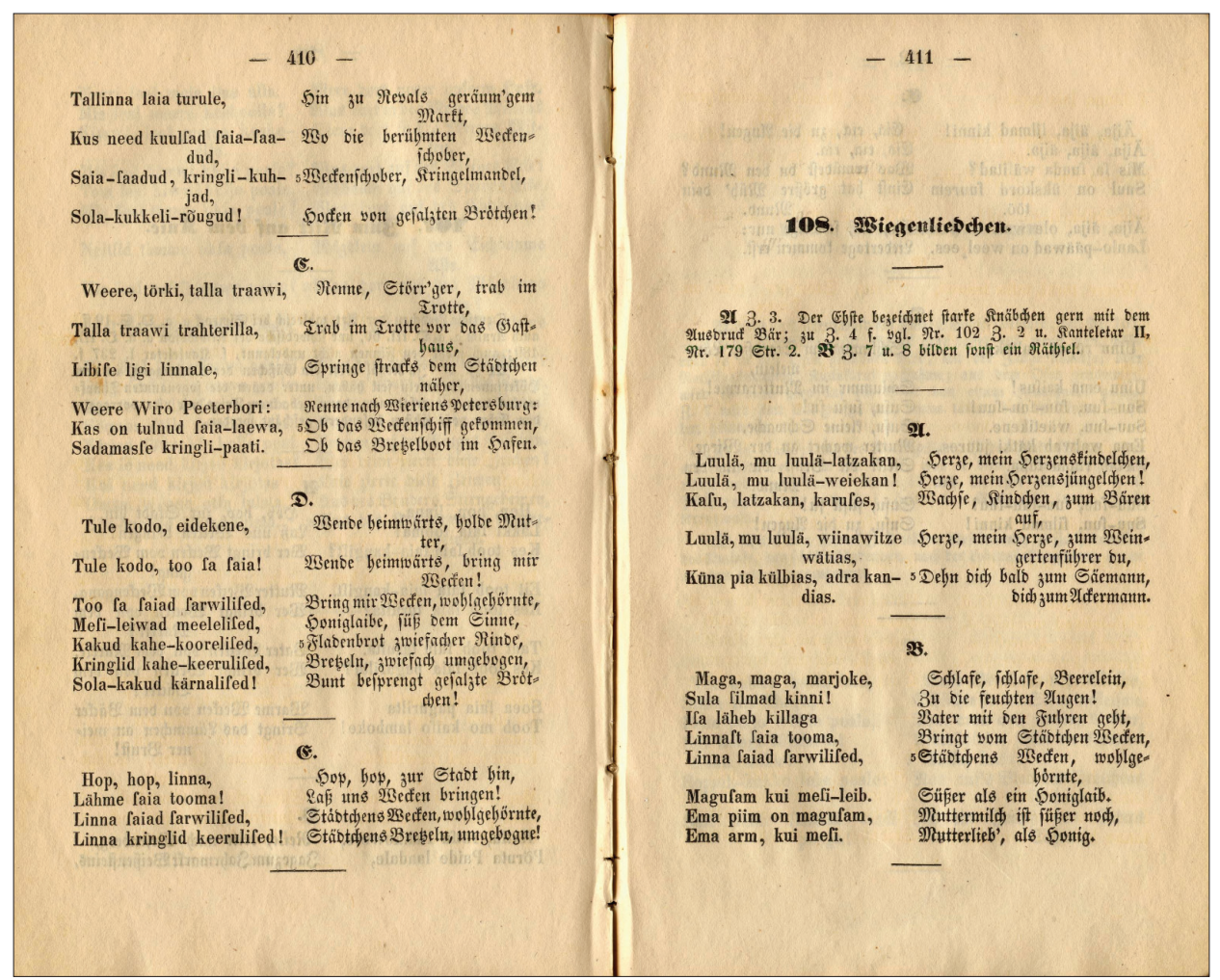

Figure 1. A page of Ehstnische Volkslieder (1850) published by A. H. Neus; page 411 starts with lullabies.

From there on, the tradition of runosongs faded; the songs tied with particular customs and practices, especially weddings and the autumn trick or treating, survived longer. From the songs sung to children, it is primarily nursery songs - accompanied by gestures and movements with practical function to amuse the child - that are still in use and can be learned from the living tradition. To some extent, lullabies follow the same pattern (Vissel 1996). 


\section{Content and form of Estonian lullabies}

I will now give an overview of the 128 lullabies from the Jakob Hurt folklore collection. These represent the oldest known layer of Estonian lullabies and give an insight into the genre as it was sung in the end of the $19^{\text {th }}$ century. I have included all songs that start with known lulling formulas and/or refer in their content to the function of putting a baby to sleep. Whereas runosongs in general show relative stability in their poetical structure and versification within geographical regions (songs written down within one region follow basically the same rules of verse form and contents), lullabies and other songs sung for children belong to the periphery of the tradition, and so do some other folk genres like incantations, proverbs, riddles, etc. Characteristically, these genres display more freedom, rhythmical variants and atypical mixing with other poetic forms. The poetics of cradlesongs combines regional characteristics of runosongs, the linguistic characteristics of dialect, esp. the lulling words, and poetical peculiarities of song-types.

A typical lullaby starts with traditional lulling or calling for the sleep to come. It can incorporate various motives from different lullabies, other runosongs with a suitable subject matter, children's songs, and improvisations. The texts may be complemented with lines consisting only of lulling words. Written records of lullabies are usually short, consisting of one or two motives in a few lines. The few examples that are longer contain either more motives or are integrated with other texts, either runosongs or improvisational material. The average length of the songs that were studied is eight lines.

Let us look at some more prominent types of lullabies in the material ${ }^{1}$.

1. By far the most frequent type is "Grow bigger" (Suisu suuremaks) with 42 texts, and "Grow so you can work" (Kasva tööle), with 34 texts. These two are quite often blended together into one song (14 instances in this material). These songs were used for uttering a wish or an incantation so that the baby would grow fast (first type), and that it will grow up and help out with various farm jobs (second type; herding cattle and sheep, sending the oxen to the field, making hay, cutting down oaks, chopping wood, picking berries, carrying water, heating the sauna (see also Sikora \& Żebrowska 2013, this volume)):

1 Lullaby types are generally very short texts consisting of one single episode, and they are easily agglomerated into longer compositions. In this sense, they can be regarded as motives (or parts of a song) rather than full songs. At the same time, they have been recorded as independent texts regardless of their shortness, which gives us no reason to consider them mere fragments instead of full songs. This decision justifies the indication of lullaby types. 


\section{Mari Sarv}

Äiu, äiu, kussu, kussu, maga, maga, maimukene!

Tsuu, tsuu suuremasse, kasva, kasva karjatsesse, äti nänni pikkutsesse, su'u võsa suurutsesse, orust hobeste toojasse, arult härja ajajasse, nänni lehma nüssijasse, äti härja hoidijasse.

Rock, rock, hush, hush, Sleep, sleep, little baby! Grow, grow bigger, Grow, grow to be a herder, As tall as your daddy and mommy, As big as your relatives, To bring the horses from the valleys, To get the oxen from the meadow, To milk the cow for your mommy, To keep the oxen for your daddy.

H II 25, 332 (7) < Tarvastu parish. - Jaak Käger (1890).

2. Song type that comes next in terms of frequency is "Come, sleep" (Tule, uni!) (with 14 instances). In this type, the singer asks the sleep to come - in the baby's eyes, on the eyelids, on the eyebrow - for the baby to fall asleep quicker. A characteristic feature of this type is that when other types usually start off with lulling words, these are not required in this type.

Tule, tule, unekene, tule, uni, uksest sisse, astu sisse akenasta, kuku sisse korstenasta.

Kuku lapse kulmu peale, lase lapse lau peale, jäe seisma silma peale.

Come, come, sleep, Come, sleep, come in through the door, Step in from the window, Fall in from the chimney, 
Fall on the baby's eyebrow, Slip on the baby's eyelid, Stand on the baby's eye.

H II 40, 613/4 (8) < Kuusalu parish. - Jakob Ploompuu \& Hans Rebane < Hans Rebane (1892).

3. The song type "Sleep towards death" (Suisu surma poole), represented with 13 texts in our material, creates an awkward atmosphere where the singer is as if waiting or wishing for the baby's death. The song is quite known and widespread, but it is not clear what the context for its use was. The comments in the typological anthology of folk songs mention that it was sung to stubborn, bad-tempered or grumbling children. Another note in the archive states that a midwife sung this song to announce the parents that the baby is not going to survive. A similar song type ("Carry the child to the realm of the dead (= Tuonela)" Tuuti lasta Tuonelahan), is known in the Finnish and Karelian tradition.

Tsuu, tsuu, latsekene, tsuu, latse, surma poole, kasva, latse, kalmu poole, kiiberde kiriku poole jala ihen, pää perän, käe risti rinna pääl, käe like liiva sisse, jala musta mulla sisse.

Hush, hush, baby Hush, baby, towards your death, Grow, baby, towards your grave, Limp towards the church, Legs first, head after, Hands crossed on the chest, Hands in the wet sand, Feet in the black sod.

H II 25, 182 (73b) < Helme parish - Matt Tomp (1890).

4. Another rather frequent song type is "Swing, kid" (Kiigu kitsetall) with 11 texts, and the type is defined primarily by its opening lines. It is evident that the combination of animal metaphor (kid of the goat) and the action, swinging, stems from the alliterative effect, which in turn defines the lulling word (this is always kiigu ('swing') in this type; only occasionally some other words are 
added to it). This type develops from the first line in a number of different ways, sometimes with only a couple of parallel verses. In a few cases, the main theme continues with the kid; in the five texts originating in southern Estonia, the opening formula is immediately continued with the song type "Mommy went to the forest to pick berries" (Memm läks metsast marju tooma).

Kiigu, kiigu, kitsõpoiga, memm läts mõtsa marjalõ pedäjädse piibuga, kadajadsõ kanniga.

Swing, swing, little kid, Mommy went to the forest to pick berries, With a pipe made of pine, With a jug made of juniper.

H III 9, 902 (13) < Urvaste parish, Koigu v. - Gustav Seen (1890).

5. The song type "Good babies into the cot" (Hä̈̈d lapsed hälli sisse), with 11 texts, focuses on praising the good and threatening the bad children (the fate of the latter is that they are stuffed in a bag).

$\ddot{A} \ddot{a}-\ddot{a} h, t s u u-t s u h$, ää latse hälli sisse, kurja latse koti sisse, pahatse latse pauna, vihatsele vitsu, halva latse hauda, jala musta mulla poole, pää valge päiva poole.

Hush, hush, Good children into a cot, Bad children into a bag, Evil children into a pouch, Angry children will be birched, Wicked children into the grave, Legs towards the black sod, Head towards the light of the day.

H III 11, 367 (1) < Urvaste parish, Restu township - Jakob Teder (1891). 
This song type displays, side by side with the traditional eight-syllable runosong, also a six-syllable lines - this is generally typical of children's songs and more widely spread across Europe (Noel et al. 2002). The six-syllable line has four metrical accents, and the last two syllables fill the whole verse foot each (shown in bold in the previous example). This metre is occasionally used in Estonian play songs, dance songs, counting verses; among lullabies, it is most often present in the type "Let the swing swing" (Lase kiik käia); represented by 3 texts in our material):

$\ddot{A} \ddot{a}$, / $\ddot{a} e, / \ddot{a} i / a$,

tuu, / tuu, / tui/a,

lase / kiigu / käi/a!

Uni / uksest / tul/la

lapse / silma / men/na!

(Lulling sounds on two lines)

Let the swing swing!

Let the sleep come in,

Into the baby's eye!

H II 65, 11 (30) < Rakvere parish. - Kristjan Raud (1894-1895).

At a closer inspection of the most frequent lullaby types, the combination of alliteration and parallelism typical of runosongs can be seen. Regardless of the rhythmical freedom and an occasional use of six-syllable structure, the songs in general follow the typical features of runosongs as well as regional special characteristics, including the use of particular typical lulling sounds and words. Lulling words can be either two-syllable (e.g. äiu, kussu, suisu, tudu, maga, kiigu) or one-syllable words (e.g. ä̈, tsuu, suu, luu). On the whole, two-syllable lulling words fit very well into the metre of the syllabic-trochaic runosongs. Only in south-eastern Estonia, where the words in language have shortened, songs have consequently adapted a different metre where a very long syllable can fill two verse positions, spreading across the entire verse foot (although the trochaic alteration of strong and weak syllables remains perceptible in the song as a whole). Thus south-eastern songs can also use one-syllable lulling words which are either short forms of the disyllabic ones (e.g. äiu ää, äh; suisu suu) or are loans from other regions. The same can be seen in the use of accentual 
six-syllable verse, like in the example above ("Let the swing swing"), which was recorded in northern Estonia. Insofar as lullabies often start with lulling words (in the entire verse or just embedded in the initial verse) and they are short, the lulling songs actually impose the rhythmical structure on the whole song. ${ }^{2}$

We can say in conclusion that the different levels of poetic expression (rhythm, euphony, figures of speech and contents) intertwine with regard to short folkloric texts (as written recordings of lullabies often are short), and are correlated with the particular features of the dialect.

\section{On the performance and use of lullabies}

A few important questions have remained unexplained thus far: namely, why are the recorded lullaby texts so short, although it is obvious that a child would not fall asleep after hearing a song that is sung only once and is just a few lines long; and secondly, why are there so few lullaby texts in Hurt's folklore collection, although their viability and practicality is widely known and extends into present day. The reason, I propose, lies in the nature of the genre - lullabies are largely improvisational and they lack entrenched textual forms. Among the archived melody collections of the later periods, there are a number of melody tablatures that lack any other text but lulling words (see the examples in Tampere 1958: 161 ff.; Kasema \& Sarv 1999). Eduard Laugaste (1974) has indeed divided lullabies into lulling songs and those dealing with the fantasies about the future of the baby. Similarly, Ingrid Rüütel (1998) stresses that lullabies are much more improvisational in terms of melody - but also in terms of lyrics - compared to other forms of runosongs (see also Saavik 2002).

Many researchers have discussed the issue of improvisation in runosongs. Singers have often stated that they can sing songs about anything they like, whereas the recordings of song texts reveal stability and typicality. One possible explanation for this contradiction is that songs that are created as socalled "occasional poetry" are born to a particular context and are as such not meant for repeating in another situation. A few songs that are tied to a certain person or their life story (autobiographical songs) have been recorded from the repertoire of Setu women (an ethnic group in the south-eastern part of Estonia;

2 A similar tendency is visible in ladybug verses (i.e. a short verse addressed at the ladybug, encouraging it to fly away from the finger; cf. Krikmann \& Sarv 2008). The first words of addressing the bug determine of on the structure of the entire verse. The address typical to northern Estonia "Lady-bug, lady-bug" (Lepa-triinu, lepa-triinu) creates a trochaic impression, whereas the address common in south-eastern Estonia "Cuckoo-bird, cuckoo-bird" (Käo-lind, käo-lind) does not. 
see Kalkun 2005), but songs related to a particular situation have rarely been recorded. The abovementioned autobiographic songs are put together using traditional and known motives which are adapted slightly to the life story of the singer. We can suppose that improvisation in lullabies has taken the same path - by combining lulling words, traditional motives, other suitable runosongs, and verses based purely on the particular context. In the beginning of 1990s, Anu Vissel organised a questionnaire study of parents concerning their habits of singing lullabies, asking what they sing to their children. Even though traditional runosongs are not sung as lullabies any more, $11 \%$ of the parents said that they have improvised (or created their own lullabies) while lulling their baby to sleep. In addition to that, Vissel mentions that "in most cases this is a momentary improvisation, which is forgotten almost at once, so it is not memorized neither by the child nor by the parent". During the time when runosongs were still regularly sung, also lullabies were probably created according to specific situations and the needs of the baby, i.e. sung ad hoc and then forgotten. Thus it is quite evident why these songs were not recorded to such an extent as some other forms of runosongs - it would have been an unusual way of collecting folklore if the folklorist was sitting by the cot and noting down the lyrics while mother was singing.

The peculiar features of verse structure also imply a greater degree of improvisation as compared to other songs. Runosongs represented, at the time they were recorded, a transitional phase between quantity-based and accent-based metre; the transition presumably took place due to changes in the language (cf. Sarv 2008). But at the same time, the transition of metre could have only taken place because song texts were continuously re-formulated, updated and complemented with new lines. These changes in verse metre are particularly visible in lullabies - there are only a few verses that display typical elements of quantity-based metre in the corpus, and the practice of filling verse positions with one very long stressed syllable, characteristic of accent-based metre, is even more frequent than in runosongs. Thus we can propose that lullaby texts have been changing more quickly and this is mainly due to their improvisational nature. In addition to that, it is probable that there are few archaisms in the texts - they have been avoided in order to make the lullaby easily understandable for the baby.

There are seven song texts in our material that contain improvised (not commonly spread) lines, like in this one:

Äia, lulla, kiigu, lulla, siis tema laulis selle laulu, kui ta lullat kiigutas, äia, lulla, kiigu, lulla. 


\section{Mari Sarv}

Sleep, baby, swing, baby

Then she sang this song,

When she rocked the baby,

Sleep, cot, swing, cot.

H II 66, 66 (33) < Kärla parish - J. Kerg (1898).

The last example of a lullaby contains several different features: lulling, traditional lullaby motives, swing song motives, and occasional (improvised) additions (in bold):

Ei ma laula teistele

ega pere poistele!

Ma laula oma lapsele!

Mino laps on linnoke,

linnoke ja lippuke,

kullerkuppu nuppuke

roosi lilli õieke.

Maga, lasta, marjakesta, kiigo, lasta, kirsipuuse,

Õ̃tsu, lasta, õunapuuse!

Susu, lasta, suuremaks,

kasva, lasta, kõrgemaks,

pisutagi pikkemaks,

raasukese raskemaks,

tangukese targemaks!

Silmad tal helkjad sinised

ja paled roosapunased.

Et on ilus isale,

eluks ajaks emale,

kenal küla poisil näha.

Enne mina laulsin lapsele, nüid aga lapse hoidjale:

"Kiiguta ja kõiguta,

ära vibu vintsuta,

läbi parre pauguta,

üle õre õotsuta!

Tead sa nüid, mis see maksab, mis seal kätkis kiikumas 
ja seal hällis õotsumas?

Pea tal maksab Pärnu linna,

keha kesked Riia linna,

silmad siidirätiku,

jalad Jaani kiriko,

kõht tal maksab kõrvi ruuna, mago maalitud hobuse."

Kiigo, kiigo, kitsetalle, äio, äio, häbariko,

ma sull annan sooja piima, meie oma lehma piima.

Äio, äio, häbariko,

kuso, kuso, kallis lasta!

I don't sing to others

Nor to boys in the family!

I am singing to my baby!

My baby is like a bird,

Like a bird and like a flag,

Like a budding globeflower,

Like a petal of a rose.

Sleep, baby, little berry,

Swing, baby, in a cherry tree,

Sway, baby, in an apple tree!

Grow, baby, bigger,

Grow, baby, taller,

A bit taller,

A tad heavier,

A little smarter!

Her eyes are shiny blue,

Her cheeks pink-red,

So that she'll be pretty for her daddy,

For a lifetime for her mommy,

For a handsome village boy to look at.

Before, I sang to the baby,

Now I'm singing to the nanny:

"Swing and rock,

Don't break the rod, 


\section{Mari Sarv}

Fall through the bars,

Swing over the perch!

Do you know now what it costs,

Swinging there in the cot,

And rocking there in the cradle?

Head costs the town of Pärnu,

Body the downtown of Riga,

Eyes a silk scarf,

Legs St. John's church,

Belly costs a tawny gelding,

Stomach a painted horse."

Swing, swing, kid,

Sleep, sleep, my weak little baby,

\section{I will give you warm milk,}

Our own cow's milk.

Sleep, sleep, my weak little baby,

Sleep, sleep, sweet child!

H II 47, 541/2 (1) < Tõstamaa parish - J. Ööwel (1893).

\section{References}

Anderson, Benedict 1983. Imagined communities: Reflections on the origin and spread of nationalism. London \& New York: Verso.

Burling, Robbins 1966. The metrics of children's verse: A cross-linguistic study. American Anthropologist, New Series, Vol. 68, No. 6, pp. 1418-1441.

ERTA 1963 = Eesti rahvaluuleteaduse ajalugu. Valitud tekste ja pilte I. [History of Estonian Folkloristics. Texts and pictures.] E. Laugaste (ed.). Tallinn: Eesti Riiklik Kirjastus.

Hennoste, Tiit 2007. Hüpped modernismi poole II. 20. sajandi eesti kirjandusteadus Euroopa kirjandusteaduse taustal. 7. loeng: esimene hüpe teksti poole 1920.-30. aastate vahetusel. [Jumps towards modernism II. Estonian literature in the $20^{\text {th }}$ century to the backdrop of European literature. Lecture No 7: First jump towards the text in the1920s and 30s.] Vikerkaar, No. 3, pp. 93-106.

Hurt, Jakob 1989. Mida rahvamälestustest pidada. Artiklite kogumik. [What to collect from folklore. A collection of articles.] Tallinn: Eesti Raamat. 


\section{Traditional Estonian lullabies. A tentative overview}

Järv, Risto \& Sarv, Mari 2013 (in press). From regular archives to digital archives. In: C. Schmitt (ed.) Corpora ethnographica online. Strategies to digitize ethnographical collections and their presentation on the Internet. Waxmann Verlag $\mathrm{GmbH}, \mathrm{pp} . \mathrm{x}-\mathrm{y}$.

Kalkun, Andreas 2005. The world of Seto female autobiographers. Pro Ethnologia, No. 17, pp. 11-30.

Kalmre, Eda 2013. Rumours and contemporary legends as part of identity creation process. In: L. Laineste \& D. Brzozowska \& W. Chłopicki (eds.) Estonia and Poland: Creativity and tradition in cultural communication, Vol. 2: Perspectives on national and regional identity. Tartu: ELM Scholarly Press, pp. 25-42.

Kasema, Maarja \& Sarv, Vaike 1999. Setu hällitused. [Setu lullabies.] Ars Musicae Popularis 13. Tallinn: Eesti Keele Instituut.

Kreutzwald, Friedrich Reinhold 1956. In: E. Ertis et al. (ed.) Kirjad A. H. Neusile, E. Sachssendahlile ja teistele 1847-1866. Fr. R. Kreutzwaldi kirjavahetus 2. [Letters to A. H. Neus, E. Sachssendahl and others in 1847-1866. Fr. R. Kreutzwald's correspondence.] Tallinn: Eesti Riiklik Kirjastus.

Krikmann, Arvo \& Sarv, Mari 2008. Eesti lepatriinusõnade levikust ja rütmikast. [On the distribution and rhythmic of Estonian ladybug verses.] In: E.-H. Västrik (ed.) Kes kõlbab, seda kõneldakse. Pühendusteos Mall Hiiemäele. [Who is worth it, will be talked about. Dedicated to Mall Hiiemäe.] Eesti Rahvaluule Arhiivi Toimetused 25. Tartu: EKM Teaduskirjastus, pp. 215-245.

Laugaste, Eduard 1974. Vanhat virolaiset alkusoinnulliset tuuditus- ja kehtolaulut. [Old Estonian alliterative lullabies and cradlesongs.] Kalevalaseuran vuosikirja 54. Helsinki: SKS, pp. 205-217.

Neus, H. 1850-1852. Ehstnische Volkslieder I-III. Reval: Ehstländischen literärischen Gesellschaft. http://www.utlib.ee/ekollekt/eeva/index.php? do=tekst_ yldandmed\&lang=1\&tid=176, last accessed on 20 May 2013.

Noel et al. 2002 = Patrizia Noel Aziz Hanna, Katrin Lindner \& Andreas Dufter. The meter of nursery rhymes: Universal vs. language-specific patterns. In: D. Restle \& D. Zaefferer (eds.) Sounds and systems. Studies in structure and change. A festschrift for Theo Vennemann. Berlin: Mouton de Gruyter, pp. 241-267.

Rüütel, Ingrid 1998. Varafolkloorsetelt vokaalžanridelt lauluni I. [From early folkloric vocal genres to songs I.] Mäetagused, No. 8, pp. 80-95. http://haldjas.folklore.ee/tagused/ nr8/ing.htm, last accessed on 20 May 2013.

Saavik, Kadri 2002. Tartumaa hällilaulud. [Tartu county lullabies.] In: M. Hiiemäe, K. Labi \& J. Oras (eds.) Lemmeleht. Pro Folkloristica IX. Tartu: Eesti Kirjandusmuuseum, pp. 202-214.

Sarv, Mari 2008. Loomiseks loodud: regivärsimõõt traditsiooniprotsessis. [Created for creation: The metre of runosongs in the process of tradition.] Eesti Rahvaluule Arhiivi Toimetused 26. Tartu: EKM Teaduskirjastus. 


\section{Mari Sarv}

Sikora, Kazimierz \& Żebrowska, Barbara 2013. Traditional Polish lullabies. In: L. Laineste, D. Brzozowska \& W. Chłopicki (eds.) Estonia and Poland. Creativity and tradition in cultural communication, Vol. 2: Perspectives on national and regional identity. Tartu: ELM Scholarly Press, pp.177-190.

Talvet, Jüri 2011. Kalevipoeg, a Great European Epic. In: F. R. Kreutzwald Kalevipoeg. Tartu-Tallinn: Eesti Kirjandusmuuseum, pp. 504-510.

Tampere, Herbert 1958. Eesti rahvalaule viisidega III. [Estonian folk songs with melodies.] Tallinn: Eesti Riiklik Kirjastus. http://www.folklore.ee/pubte/eraamat/tampere/ tampere3/, last accessed on 20 May 2013.

Vissel, Anu 1996. What is sung to children at Estonian homes today? In: I. Rüütel $\&$ K. Kuutma (eds.) The family as the tradition carrier. Conference Proceedings. NIF Publications, No. 31, Vol. 1. Tallinn, pp. 183-191. 